\title{
Approach of Religious Intellectuals regarding to Religion Function Before and After Islamic Revolution in Iran
}

\author{
Hamid Sarmadi ${ }^{1 *}$, Morteza Badri ${ }^{2}$, Sirous saadati ${ }^{2}$, Jafar Ghanei ${ }^{3}$ \\ ${ }^{1 *} \mathrm{Ph} . \mathrm{D}$ of Political Science, Department of Politics and Law, Science and Research Branch \\ Islamic Azad University, Tehran, Iran \\ ${ }^{2}$ Ph.D Student of Political Science, Department of Politics and Law, Science and Research Branch \\ Islamic Azad University, Tehran, Iran \\ ${ }^{3}$ M.A student in international at Bonb azad university \\ hamedsarmadi2000@gmail.com
}

\begin{abstract}
Religious intellectual in Iran is dynamic process that has been began within one hundred years ego and those intellectuals that don't enough traditional reads reasons to resolve theoretical issues and try to rely on modern science adapt religion presence in modern world.
\end{abstract}

As far as effect to this process has been three elements: theoretical questions of term, scientific problems, and knowledge and people age cognizance. Words like that revival, reform, pluralism, hermeneutic and... is western received concepts that Iranian intellectuals sue adaptation with doctrines of traditional religion.

Generally religious intellectual in Iran pass from three period: 1.before constitutional age 2.age 1941-1960 that strong point is coup 3.divide in two period: number one is Islamic revolution intellectuals and secondary after revolution intellectuals this periods including are sequence of three general readings: ideologicallyscientifically-epistemologically.

Before Islamic revolution religious intellectuals have outlook of external about religion and regarding concepts of absolutism, idealism, religion presence in public and privacy domain and sue consistency of religion and politics and putative this agent in eradicate of oppression. Whereas post-revolution religion intellectuals sue ponder in modernism concepts and express self imagination in concepts of justice and freedom compatible this base and have outlook of impressionistic between religion, age and position and those subjects. Abdolkarim Soroush believe rely to intra-religion resources is not enough, instead regarding to discuss and rationality and endeavors indicates religious sensitive in adaptation of pluralistic and democratic properties.

Keywords: ideology - pluralism - intra-religious attitude - extra-religious attitude - hermeneutic

\section{THEORETICAL BASIS}

\section{Kinds of religious intellectual}

More than formal religion researchers in history intellectual religious in recent century, had exist in most of secular intellectuals expediency, instrumental, vulgar and conservative outlook to religion and clericals. Mirza malkam khan recommended to friends, after presenting of western socio-philosophical principals told that Islam is resource of this principals. Too yousof khan mostashar-aldoleh explain western and French rules with blond of Islamic rules. So they try presenting modernization idea to society in wrapper packet of religion because of themselves thoughts don't effect contrast of Islam and religion (Broujerdi).

Generally religious intellectual in Iran from beginning passed three period: 
Approach of Religious Intellectuals regarding to Religion Function Before and After Islamic Revolution in Iran

1. Period of before constitutional, constitution and Reza shah period that was main characters Seyyed jamalaldin asadabadi, ayatollah naeeni, ayatollah tabatabaee and behbahani. Religious intellectuals in this period was reaction against enter of modern thoughts and process of western modernization and formed from modulation of this thoughts with religion principals.

2. Period of empirical intellectual that is from august of 1941 to end of 1950 decade. Turning point of this point Coup of 19 august 1953 and main character is ayatollah kashani.

3. Third period divide to two period: first beginning from 1961 and turning point is Islamic revolution in 1979 and main character is Shariati and Bazargan. Second are post revolution religious intellectuals such as Soroush, Shabestari, Malekian, Naraghi and etc. this three period in format of theories adapted to three general descriptions:

Ideological statement: meaning that interpretation of religion alike action index and mundane platform. In other word use of religious elements in rehabilitate of an ideology for social change. Indexes of this reading are:

a) change of current position

b) emphasis to political and practical project

c) stockade between self and others

d) create of expectancy basis of religion doctrines

scientific statement: principal scientific reading on adaptation of religion and science. Based on religious intellectuals by means of adaptive independent judgment try to prove that first religious propositional are logical-rational so not only adapted to neo-science but also neo-science can explain religious propositions. On the other hand scientific propositions have religious origins.

Secularization statement: this reading began and growth after Islamic revolution in Iran. Main characteristics is stressed to researches program, gradual reform of traditional religion, separation of religion realization from religion and humanization of religious knowledge that open window to critic of religious realization, reduction of expectation of religion and historical attitude to religion that cause conceptual of religion be critics. This reading believe categories like that freedom, democracy, human rights and wisdom have forms of extra-religion and Islam should be adapt them and religionization of society don't inclusion of every things.

period of second Pahlavi and Islamic republic was turning point governmentally structure in religious intellectual. This process became resultant synthesis of western leftist and religion center with scientism and rationalism that in result create two kind of intellectuals: 1 . Leftist and revolutionist religious intellectual and 2. Liberal religious intellectual. Critical and revolutionist Islam belong to Ali Shariati that followed restitute of individuals and society to values and primary Islam traditions and too Alavi Shiite and then add with dimensions of positive and requirements of modern civilization like that justice and freedom to change of Islam to combat of colonial, arrogant and dictatorship. In other hand scientific and liberal religious intellectual that was first descendant in Iran that acknowledge Islam with scientific results and present type of Islam that follow after 60 years. New religion center process not accept titles such as religious intellectual or Muslim and scientific and religion contrast and modern achievements. This current not recognize religion as lag agent, stereotype and nor able not response for modern demands and on the contrary believe that revert to pure religion and reject of tradition superstitions can adjustment of Islam according to new requirements and scientific and change those to propulsion of society. Mission of this current is values and Islamic rules redefinition, critic of traditional Islam and advocators and commensurate with current thoughts and synthesis together. Mainspring of this current that believe to Islamic rules is contrast and confrontation to masses and material and secular groups that prior like introduce religion contrast to science. 
Approach of Religious Intellectuals regarding to Religion Function Before and After Islamic Revolution in Iran

Both of left and right currents has been knowledge of religion effects in create of motivation and evolution in society and those potential abilities in stimulation of individuals. Other similarity is that both currents believe tradition religion and tradition custodians cannot realize religion dynamics and modern aspects consistent with modern world. On this reason they want and wanted with refuse of traditions, superstitions and religion bring out of tradition clerical hands, unbrace of creation, innovation and progress methods

\section{Past-Revolution Dominant CurRent}

Religious intellectuals in Iran before 1979 revolution follow connection of religion and politics and applicant religion as effect element in eradicate of corruption and downtrodden. So sue Islamize of politics and influence of religion in socials and politics and try use of holy texts for social interests that inclusion of three currents: 1. Current base of religious thoughts that Bazargan was predominantly in this axis. 2. Current of leftist Muslim that intellectually was in Ali Shariati. 3. Current part of religious special that was concentrate on Fatwa, religious characters and religious jurisprudence that including in thoughts of ayatollah Tabatabaee and Motahari. First and second currents is main argument of this article before victory of Islamic revolution attemptalong with other revolutionist currents for overthrow of Pahlavi regime. So take themselves ideologue and indication, thoughts persons like Shariati as intellectual current indication and too ayatollah Khomeini from religion and tradition arena and others and totally defense thesis integration of religion, politics and government. Shariati present new interpretation from revolution movement direct to Islamic doctrines with connection main elements of tradition and modernity by revolutionist ideology (Pedram 76). So in past period of revolution prevalent concepts such as revolution, factionalism, classless society, socialism and e.tc and religious thinkers like that Ali Shariati and Mahmud Talegani proceed to theorize in finite dimension. Too most of religious intellectuals sue compilation positive aspects of religious tradition and modern ideas and modern institutions achieve to Islamic society. Most of this intellectuals pertain warranted Shariati and others intellectual endeavors for construe concepts such as justice, freedom and genuine democracy and socialism under reconstructed Islam about refer to genuine society culture and his desires for overcoming to alienation by ideologic model on absolute Islamic renaissance. In this period religious intellectuals accept or reject concepts of tradition and modernity without discovery those aftermath and consider those as appropriate or inappropriate option for attain to ideal political and social system (Shariati, Ali 77-78). Between of tradition Islam representatives that take it this concepts such as ayatollah Motahari and Khomeini but proceed gradually critic of some religious intellectual thoughts and Marxists.

More than Shariati, Bazargan presented pattern of Islam that to be consistent with science and society in modern era. This pattern be based on Islam compatible with modern world requirements with emphasis of axis role of labor, responsibility, work consciousness, Islam impressive role in prosperity and those capability for compete with competitions (spatial Marxism). In his believe "a virtual civilized person wholly is a social person that overpass individual interests instead social responsibilities". In this base believe that Islam is influential generate program for mundane and otherworld life. He considered freedom in mean of liberal and take political act based on liberal democracy ideas and compatible them but don't consider during of revolution period transformations according to revolutionist exigencies in latest decade of 70 and then suppressed by grow of Islamic radicalism. With establish of Islamic system and Islamize of sovereignty, religion exposure versus big historical examination and during of post-revolution period, Bazargan amendment his outlook about Islam interference in politics. This reform based on government experience by clericals in period of post revolution. In outlook of Bazargan affairs such as politics and society management assignation to humans and like of other affairs can arrange by experiment and rationality.

\section{Post-Revolution InTEllectual Religious}

Last confrontation of religious intellectuals with modernity accompany with difference and sometime contrast approaches to Islam. This approaches religiously divide to three category including deny, accept and modernity 
selection. This Islamic ideas indicate to defect of orientalism outlooks in analysis of religious intellectual in society like that Iran, because orientalism entail refuse interfering of Islam and modernity horizons and so entail refuse of Islam fulfilment positive role and even different role in creation of political and social theories. In period of post-revolution, accept and rejection of institutions and modern ideas, joint predominantly with cogitate in concept of modernity and pillars. In this period religious intellectuals ponder in concepts such as rationality, modern science, progress and promotion and secularization process and eventually try express themselves imagine of justice and freedom on this base. In past-revolution period most of religious intellectuals defense of modernity with consideration of advance technical instrument and some of modern ideas and institutions like that democracy, human rights, representative and administrative system but in post-revolution period all of this issues has been and gets analysis in theory and practical with consideration of insightful fundaments, manner and modernity results. Ideology issue and those critic presented liberally by Abdolkarim Soroush with analysis of ideology position in an Islamic government and religion interference with government (Pedram 83). His challenge to an ideological government entice attention many of religious intellectuals of political system that establishment by clericals.

Soroush explain and justify concepts of rationality, modern science and progress in form of secularized religion and presented epistemology in base of analytical philosophy to express axis of experiment and human knowledge in realize of phenomenon. In this base, in level of political and social theory, he indicate results of liberalism in religious societies. then explain justice and freedom haven't applicable prove from religious propositions and should be consider them as general human values that evaluate out of religion arena. Soroush stressed on humanize of religious knowledge and those evolution supplement in effect of other human knowledge. He argue that religious knowledge become constrict and expand in any person and any era by constrict and expand sum of knowledgements. This epistemology categorize in seven parameters:

1. sharia is invariant and what changing is perception.

2. any new perception of sharia is based of internal and external pillars.

3. perception of sharia changing constantly.

4. Changing of perceptions depend on internal pillar, meaning that religious scholars knowledgement.

5. Secularize of religion not only meaning resolve of new problems but also meaning compatible of religion knowledge with other knoledgements.

6. New of perceptions don't meaning religion evasion.

7. Sharia perception depended on external basis of sharia.

Too religious knowledge like that any other knowledge is result of human discovery and contemplate and is synthesis of suppositions, certainties, rights and voids and change and evolution of this class (Soroush, constrict and expand_22, 269-270).

Between of religious intellectuals in Iran happen endeavors to explain of Islam and democracy connection. Shariati synthesis engaged democracy as native western democracy with religious doctrines. His reconstruct of Islamic concepts such as Imamah, administration, council, blasphemy, gnostic, theism and ... under sum of modern ideas such as freedom, intellectual, justice, social rights and democracy be powerful motive force in mobilization of intellectuals despite dominant of leftist thoughts not allow to provide perusing in actual content of this concepts (Broujerdi, 39-40).

Religious intellectuals call formal of religion arenas confrontation to modern world questions. Soroush consider to critic of religious ideological narrative and analysis critically Shariati theory of Imamah and Emmett and eventually present of religious democratic government try reconcile religion with democracy. He present two kinds of religious insight: 
Approach of Religious Intellectuals regarding to Religion Function Before and After Islamic Revolution in Iran

First, maximalist insight or maximalist anticipation that believe all of information, measures, enough and necessary rules for economy, government, commercial, law, ethic theology and e.tc for any mind including simple and complex entered in sharia and so believers don't need any resource.

Second, minimalist insight that believe sharia learn us necessary minimum and nor more. So intellectual religious should be with minimal outlook emancipate religion from control of Fiqh, government and political power to can assist to Muslim spiritual affluence.

Malekian is one of the religious intellectuals that have methodological thoughts in approach of quotidian issues. He has three impressions on Islam word: first Islam is some of Muslims holy texts like that Quran and tradition that upper than dispute. Second Islam is practical Islam. Third Islam sum of descriptions, interpretations and analysis that provided along of Islam history by Quran interpretations, narrative descripts, philosophies, mystics, theologians, ethic scholars and jurisprudents. In his believe variety Islam having different answer to questions.

Democracy partials in religious framework in Iran divide two main groups: 1. Those contemplate to reform of Islam for reconcile to democracy (religious democracy) and 2. Those contemplate to amendment of constitution for secularization and create of secular democracy (liberal democracy). Basic assume of this thoughts is on basic differences between two political and intellectual system about ontological, epistemological, anthropological and political system functions (Tagavi, 98).

\section{TURNS OF THEORY BASIS}

Past-revolution branch of religious intellectual is synthesis of Islam, nationalism and socialism that have two common bases: A) westernization B) religious modernization or religion reform. This currents have two parameters:

- $\quad$ Believe to Islam except clericals

- Believe to supremacy of empirical science and interpretation of Quran and religious concepts base on positivism and hermeneutics.

After Islamic revolution, religious intellectual create basic transform in literacy and religion centric and connection with religion because of revolutionary and religious sovereignty discourse supremacy to other current discourses under clericals current, special ayatollah Khomeini thought line. Claim of religious intellectual current after revolution is that traditional religion haven't consistent with new civilization achievements and clericals aren't only religion interpretations. Those outlooks haven't different with religious and secular intellectuals and alike of modern world intellectual currents cannot ignoring religious discoveries and achievements in variety dimensions. Tradition in those outlooks has been catch to obscurity, inability and insufficient in new world and modernity and modernization haven't able to institutionalize in individuals mental structure, because is imported, superficiality and would be unlike with accepted society traditions. Solution of this current is that should be create synthesis and coordination between this achievements and religion. So more than critic of society and Islamic republic system, in reform dimension take to comply of religion with modernity in rational meaning and receive in coordinate of variety rational readings and religion epistemological. Too Thought and politically trend take to critic of Islamic republic system and religion sovereignty discourse (forough, 130-145).

Generally can mention contently religious intellectual move frankly to liberal intellectual aims and approximately defense alike to laic and secular intellectuals from alike non-religious government structure although not necessarily non-religious. Despite of this content changes, religious intellectuals express his claims under religious reasons and strictly abide against those that call liberal, secular and non-religious and statement many 
Approach of Religious Intellectuals regarding to Religion Function Before and After Islamic Revolution in Iran

argumentations in exigency religious of intellectual in Iran society. So any change and reform should be pass by religion and should consideration to social dimension of religious life and don't consider only to individual and rational dimensions of modern human. On base of this attitude, mentioned confrontations attain to any result and reduction to quasi-modern in society alike of past periods (Hashemi, 142-143).

Moreover religious intellectuals consider district of religion arenas and rely on self-founded wisdom as main mission for attain to ideal society and pass from tradition to modernity and set up of modern society. In this society religion cannot be in political and social arenas that call as general arena that take delimitation between religion and government and so restrict of religion and reduction to individual-obligate affairs and not social. This endeavors leading scientific and concrete differentiation between religion and politics and sometime debris in theoretic level. Actually thought evolvement from Islamization to secular Islam. Soroush believe that religion is corpulently from ideology and basically ideologies are anti-rationality and wisdom and are hostile of human and systematic wrong of wisdom.

Despite of ideological outlook, enter of secular thoughts, knowledge sociology, pluralism, epistemology, scientific religion and e.tc, open manner to equality between science and religion. Human as rational person can recognize welfare and evil, by this recognize inconvincible against antecedent traditions because recognize incompatible of current requirements. This important result enter of positivism and empirical sciences in modern era (Kazemi, 65).

One of the intellectuals religious is Mojtahed Shabestari. He applicant of hermeneutic methodology critic formal recitation of religion and believe public information, admissions, jurisprudent anticipations and interests whether political and social issues and whether worldview conducted his for inferred. Too believe that in modern era, modern human too enhancement possible of quality choice for human and too have been raise non-religious quantity measures. He consider government as exterreligious affair. so applicant of religion as governmental manner is detriment of both because government and politics is rational and rationality that carried commensurate with policymaking exigencies and not invariable principals. Moreover religion language is prayer and obligate center ethic and rules language and not ideology language and rational philosophy and when religion evolve into ideology, both lose its language and gain one ideological language and so become absurd from its identification (Shabestari, 236-237).

\section{ERA KNOWLEDGE AND SECUlaRization OF RELigion}

Era knowledge of religion should be include as part of secularization subdiscourse that religious intellectual in decade of 90 are those represents. In secularization discourse, instead change of political and social situate that is base on invariable perception on religious rules, religion change base on civil status, meant contents such as democracy, human rights, equality and rule situating based on religious realize and religious knowledgement that inherently are secular contents. Modernization of religious knowledge providing new possible for advent of secular perceptions that can has been themselves unique position. Soroush theory of constrict and expand of sharia presented in subdiscourse of religion secularize and sue creation of minimal religion to challenge classic religion knowledge authority. Base of this theory is on dissociate between nature of religion or what realize by prophet and perception of religion or what realize by Muslims. Moreover, his critic from ideology including Marxism ideology and ideological Islam as cited in Shariati thoughts assist religious pluralism to be advance. He emphasis to pluralism in social theory arena as liberalism principal and led epistemological pluralism basis of social pluralism. Soroush in defense of rationality presented justice content and reject idea that express justice and freedom are two contrast categories and then explain if this categories (entitled contrast of socialism and democracy) being separate, is imaginary contrast. In his believe if consider justice as realize all of humanity rights, in this case freedom is one of this rights and indeed freedom is one of the justice components and so justice without freedom isn't perfect (Pedram,16). Soroush believe justice is include of comprehensive humanity 
Approach of Religious Intellectuals regarding to Religion Function Before and After Islamic Revolution in Iran

means and cannot restrict to religious rules and religious justice based on sharia rules that directly construe from Quran. Actually nature of Soroush religious government no different with other humanity governments and religious aspect is only to exigency of humanity society and not base of government nature and manner of governors. So Soroush explain that religious government is essentially humanity government and not less and not more and should be alike of other governments. He differentiating between religious revelational nature and humanity knowledgement. Revelational religion is surd and immune from revision, inverse humanity knowledgement in religion is interpretation from religion that is relative, related to era and incomplete human discovery. So in this category, human kind confront to religion humanity knowledgment and fact of religion is far-reaching and realize of new knowledgement, merely don't enhance prior knowledgements but impressing all of process (Soroush, constrict and expand theory, 307, 361-365).

\section{CONCLUSION}

Religious intellectual thought began after twenty century and in last decade of 50 and 60 enter to political campaign aspects and vast its attempts. After 60 decade and among of political campaigns, formed philosophical basis that be synthesis of religious thoughts and principals of western thoughts such as liberalism and Marxism. Before of Islamic revolution in Iran, religious intellectuals sue compatible of religion with modern ideologies special socialism and essentially religion interpretation be for transform to revolutionary ideology. After Islamic revolution, intellectuals attempt with reinterpretation of religion, unshackled it from politics, revolution, ideology and intra-religion attitude. Stress of dominant current in past-revolution on capitalism, imperialism, justice, freedom and return to essential traditions but after 80 decade, intellectual religion with emphasis to liberalism and secularism confront against Islamic radicalism and provide manner for resolution in modernity. So tradition discourse led contents such as absolutism, religion presence in public and private fields, idealism, originality of sharia rules, motivation of religious sensibilities, clericals authority and adversary to west as whole and revision of tradition but post-revolution current have impressionistic outlook to religion, time, position and those subject. This class have scientific perception to religious issues and with advocate of positivism, empiricism and hermeneutic reading, consideration to religious contents analysis and don't believe to Ijtihad of tradition Fiqh. Those base in politics, separate of religion and politics and since are engage to sharia, haven't metaphysical understanding from religion and in his believe would abide religion in holy aspect and presented only mundane politics to society. Too believe everybody base of his knowledge use and apply religion texts. So intended democratic government concomitance with Islamic values and religious attitude to democracy rely on self-founded rationality. They endeavor by present of minimal Islam and exception of Fiqh and extra-religion and multidimensional approach sue reconcile between Islam and democracy. Generally intellectual base of last generation instead empirical finality mean what considered by revolutionary religious intellectuals, is critic wisdom that don't alleged definite recognize of world, and always considerate to doubt, critic, new detection and ontological hermeneutic.

\section{REFERENCES}

1. Hashemi, Mohammadmansour; Modern religious intellectuals from Shariati to Malekian; Tehran: Kavir press, 2006.

2. Jahanbakhsh, Forough; Islam, democracy and religious modernism in Iran from Bazargan to Soroush; translated by Jalil Parvin; Tehran: Geme now press, 2004.

3. Taghavi, Seyyed mohammadnaser; Religion and democratic fundaments; Tehran: culture research and Islamic thoughts publications, 2006.

4. Kazemi, Abbas; Sociology of religious intellectual in Iran; Tehran: culture ministry publications, 2004.

5. Mohammadrezaee, Mohammad; Provenance of religious intellectual; Tehran, Zolale kosar press , 2002. 
Approach of Religious Intellectuals regarding to Religion Function Before and After Islamic Revolution in Iran

6. Mojtahede shabestari, Mohammad; critical to religious formal citation; Tehran: Aban press, 2001.

7. ; Hermeneutic, Quran and tradition; Tehran, Tarhe now press, 1996.

8. Pedram, Masoud; Religious intellectuals and modernity in Iran after revolution; Tehran: Game now press, 2003.

9. Borujerdi, Mehrzad; Iranian intellectuals and west; translated by majid shirazi; Tehran: Foruzan press, 2005.

10. Farasatkhah, Maghsoud; Began of religion and non-religion intellectual; Tehran: Enteshar cooperation company, 1995.

11. Shariati, Ali; Sets of works; Tehran: Elham press, 1983.

12. Soroush, Abdolkarim; Constrict and expand of sharia theorize; Tehran: Serat press, 1991.

13. ; Mistery, intellectual and faithful; Serat cultural institute, 1998.

14. Tradition and secularism, speeches from Soroush and others; Tehran: Serat press, 2002.

Citation: Hamid Sarmadi, Morteza Badri, Sirous saadati, Jafar Ghanei. "Approach of Religious Intellectuals regarding to Religion Function Before and After Islamic Revolution in Iran" American Research Journal of Humanities and Social Sciences, vol 4, no. 1, 2018, pp. 1-8.

Copyright (c) 2018 Hamid Sarmadi, Morteza Badri, Sirous saadati, Jafar Ghanei. This is an open access article distributed under the Creative Commons Attribution License, which permits unrestricted use, distribution, and reproduction in any medium, provided the original work is properly cited. 